\title{
La Convención de Nueva York: antecedentes y objetivos
}

\author{
Jose Luis Repetto Deville \\ Andrea Espejo Donaire
}

\begin{abstract}
Resumen.- En el presente artículo se explica la historia de los reconocimientos de laudos a lo largo del tiempo hasta llegar a la Convención de Nueva York. Asimismo, se tratan los beneficios que generaron los cambios en la ejecución y reconocimiento de laudos extranjeros a partir de su entrada en vigencia.
\end{abstract}

\begin{abstract}
In this article the authors explain the history of award recognition through time to the New York Convention. Additionally, it treats the benefits that generated the changes in execution and recognition of awards since its effective date.
\end{abstract}

Abogado titulado con mención "Sobresaliente Cum Laude" por la Universidad del Pacífico. Jose Luis es co-autor de la tesis "Reconocimiento y ejecución de laudos anulados en la sede del arbitraje: análisis al amparo de la Convención de Nueva York". Asociado del Área de Arbitraje de Miranda \& Amado. Cuenta con experiencia representando clientes en arbitrajes de inversión y arbitrajes comerciales. $\mathrm{Su}$ experiencia incluye la representación de clientes en procedimientos de reconocimiento de laudos extranjeros bajo la Convención de Nueva York. Es autor de publicaciones de arbitraje en diversas revistas especializadas. Ha sido entrenador del equipo que representó a la Universidad del Pacífico en diversas ediciones de la Competencia Internacional de Arbitraje. Fue presidente del Consejo Directivo de la Asociación DERUP Editores - Forseti.

Abogada titulada con mención "Sobresaliente Cum Laude" por la Universidad del Pacífico. Premio Robert Maes Especial a la Excelencia Académica (Primer Puesto de los Egresados de la Facultad de Derecho de la Universidad del Pacífico, Promoción 2015-II). Andrea es co-autora de la tesis "Reconocimiento y ejecución de laudos anulados en la sede del arbitraje: análisis al amparo de la Convención de Nueva York". Asociada del Área de Regulatorio del Estudio Echecopar, asociado a Baker \& McKenzie. Cuenta con experiencia representando clientes en arbitrajes de inversión y arbitrajes comerciales. Ha sido entrenadora del equipo que representó a la Universidad del Pacífico en diversas ediciones de la Competencia Internacional de Arbitraje. 


\section{Introducción}

Encontrándonos próximos al sexagésimo aniversario de la Convención de Nueva York de 1958 sobre el Reconocimiento y la Ejecución de las Sentencias Arbitrales Extranjeras, no podemos dejar de ofrecer un breve comentario a uno de los tratados más exitosos en materia comercial, y sin duda alguna, el tratado más relevante en materia de Arbitraje Internacional ${ }^{1}$.

Como se sabe, la Convención de Nueva York regula dos aspectos de gran utilidad práctica en el tráfico comercial internacional: la ejecución de acuerdos arbitrales por las cortes (también conocida como la remisión de las partes a arbitraje o excepción de convenio arbitral) y el reconocimiento de laudos extranjeros. 2 Si las cortes judiciales no remiten a las partes ante la existencia de un convenio arbitral o si las cortes judiciales no reconocen laudos dictados en el extranjero, que son justamente los dos aspectos regulados en la Convención de Nueva York, el arbitraje como foro de resolución de controversias carece de sentido y de ventaja frente a la jurisdicción ordinaria.

Pese al tiempo transcurrido desde su entrada en vigor, este instrumento internacional continúa plenamente vigente y resulta de especial importancia para todos aquellos que aspiramos a estudiar el Arbitraje Internacional o que nos enfrentamos al pedido de un cliente de reconocer $u$ oponerse al reconocimiento de un laudo extranjero.

Por ello, es indispensable conocer sus antecedentes históricos y principales características de manera que se entiendan muchos de las bases que en las que hoy se fundamenta el Arbitraje Internacional y que han promovido que esta se vuelva el método natural de solución de disputas en materia comercial internacional.

También es importante conocer este tratado porque fue el antecedente normativo que inspiró la creación de la Ley Modelo UNCITRAL. A su vez, la Ley Modelo UNCITRAL terminó inspirando la Ley Peruana de Arbitraje (aprobada mediante Decreto Legislativo 1071).

1 Como bien sostiene Michael Mustill, "[The New York Convention] perhaps could lay claim to be the most effective instance of international legislation in the entire history of commercial law." MUSTILL, Michael. Arbitration: History and Background. J. International Arbitration 43, 1989; citado en PAULSSON, Marike. The 1958 New York Convention in Action, Kluwer Law International, 2016, p. 21.

2 Sin perjuicio de ello, la Convención de Nueva York no regula los demás aspectos referidos al arbitraje como son la competencia de los árbitros para definir su propia competencia, la separabilidad del convenio arbitral, los requisitos aplicables a los árbitros o al procedimiento, pero sobre todo no regula los recursos contra los laudos arbitrales. Esos aspectos del arbitraje son regulados por la legislación arbitral de cada país. Por ello, si bien la Convención de Nueva York es la fuente de inspiración del arbitraje a nivel internacional, no se debe descuidar en el análisis la legislación nacional del lugar donde tenga su sede del arbitraje. 
A continuación, desarrollaremos los principales antecedentes de la Convención de Nueva York, los mismos que explican la finalidad y objetivos de la creación de este tratado, y luego estudiaremos la regulación prevista en la propia Convención; de manera que se pueda entender un poco más la relevancia de este instrumento y lo que busca promover.

\section{Las Antecedentes Normativos de la Convención de Nueva York}

A 1958, año en que se adoptó la Convención de Nueva York, existían dos tratados que regulaban distintos aspectos del arbitraje: el Protocolo de Ginebra y la Convención de Ginebra.

\section{i. Protocolo de Ginebra}

A inicios del siglo $X X$, el arbitraje comercial internacional se basaba exclusivamente en las leyes arbitrales domésticas de cada país. ${ }^{3}$ Muchas de las leyes nacionales eran hostiles al arbitraje. No solo ello, sino que eran diferentes de país en país y las autoridades judiciales veían al arbitraje como su rival.

Tras la Primera Guerra Mundial y bajo los auspicios de la Liga de Naciones y la recientemente creada Cámara de Comercio Internacional (CCI) en París, se hicieron esfuerzos para remover los obstáculos que existían contra el arbitraje comercial internacional.4 Así, en palabras del profesor Gary Born, los "comerciantes de los Estados desarrollados incrementaron sus esfuerzos en realizar cambios de legislaciones para facilitar el uso del arbitraje para resolver controversias domésticas y particularmente, controversias internacionales comerciales. Apelaron a enfatizar la importancia de mecanismos justos, efectivos y confiables para resolver controversias internacionales a fin de expandir el comercio internacional y la inversión ${ }^{5 \prime}$.

3 VAN DEN BERG, Albert Jan. The New York Convention of 1958. Kluwer Law and Taxation Publishers, La Haya, 1981, p. 6.

4 GAILLARD, Emmanuel y SAVAGE, John. Fouchard Gaillard Goldman on International Commercial Arbitration. Kluwer Law International, 1999, p. 442.

"Two multilateral conventions were drawn up under the auspices of the League of Nations in Geneva following World War I. They removed a number of obstacles then facing international arbitration".

5 BORN, Gary. International Commercial Arbitration. 2da edición, Kluwer Law International, 2014, p. 64.

"During the first decades of the 20th century, businesses in developed states made increasingly urgent calls for legislation to facilitate the use of arbitration in resolving domestic and, particularly, international commercial disputes. These appeals emphasized the importance of reliable, effective and fair mechanisms for resolving international disputes to the expansion of international trade and investment. In the international context, the newlyfounded International Chamber of Commerce (established in 1919) played a central role in efforts by the business community to strengthen the legal framework for international arbitration". (Traducción libre) 
El resultado fue el Protocolo de Ginebra. ${ }^{6}$ Este tratado de tan solo tres páginas, declaraba como válidos aquellos acuerdos arbitrales para remitir futuras controversias a arbitraje. ${ }^{7}$ Como se sabe, a dicha fecha la gran mayoría de jurisdicciones no establecía como válidos y ejecutables los convenios arbitrales para remitir futuras controversias a arbitraje. Solo eran válidos los convenios arbitrales que remitían controversias existentes a arbitraje.

El mencionado instrumento internacional también establecía la obligación de las cortes de los Estados contratantes de remitir a las partes a arbitraje cuando exista un compromiso de arbitrar. A esto se le conoce en nuestro país como la excepción del convenio arbitral. ${ }^{8}$

Asimismo, el mencionado tratado tenía un marcado tinte territorialista, al disponer que el procedimiento arbitral debía llevarse a cabo de conformidad con el acuerdo de las partes y por la ley del país en cuyo territorio tenga lugar el arbitraje. ${ }^{9}$

El impacto que tuvo este tratado fue significativo. Sentó las bases de los principios más elementales del arbitraje comercial internacional como lo conocemos ahora: la posibilidad de remitir controversias futuras a arbitraje, la

6 Este tratado entró en vigor el 28 de julio de 1924. Los siguientes Estados depositaron instrumentos de ratificación, adhesión o notificación: Albania, Alemania, Austria, Bélgica, Brasil, Checoslovaquia, Dinamarca, España, Estonia, Finlandia, Francia, Grecia, India, Irak, Irlanda, Israel, Italia, Japón, Taiwán, Luxemburgo, Malta, Mauricio, Mónaco, Noruega, Nueva Zelanda, Países Bajos, Polonia, Portugal, Reino Unido de Gran Bretaña e Irlanda del Norte, Rhodesia del Sur, Guayana Británica, Honduras Británica, Ceilán, Islas Malvinas (Falkland) y Dependencias, Gambia (Colonia y Protectorado), Costa de Oro (incluidos Ashanti y los territorios septentrionales de la Costa de Oro y Togo), Gibraltar, Jamaica (Islas Turcas y Caicos e Islas Caimán), Kenia (Colonia y Protectorado), Islas Leeward, Malta, Mauricio, Rhodesia del Norte, Palestina (excluida la Transjordania), Transjordania, Islas Windward (Granada, Santa Lucia, San Vicente), Zanzíbar, Tanganyika, Santa Elena, Uganda, Bahamas, Birmania, Hong Kong, Suecia, Suiza, Tailandia y Yugoslavia. Los siguientes Estados firmaron el Protocolo: Bolivia, Chile, El Salvador, Letonia, Liechtenstein, Lituania, Nicaragua, Panamá, Paraguay, Perú, República de Corea, Uganda, Uruguay.

7. Nos referimos, pues, a la diferencia entre la cláusula de compromiso y el compromiso arbitral. De este modo, el Protocolo de Ginebra, establece en su artículo 1 que: "Los Estados contratantes reconocen la validez, entre partes sometidas a la jurisdicción de Estados contratantes diferentes, tanto del compromiso como de la cláusula compromisoria por los que las partes de un contrato se obligan, en materia comercial y en cualquier otra susceptible de ser regulada por vía de arbitraje por compromiso, a someter total o parcialmente los diferendos que puedan surgir del referido contrato a un arbitraje, aun en el caso de que éste deba tener lugar en un país distinto a aquel a cuya jurisdicción están sometidas". Protocolo relativo a las cláusulas arbitrales aprobado en Ginebra el 24 de setiembre de 1923. Artículo 1.

8 El Protocolo de Ginebra reguló la denominada "excepción de convenio arbitral". Así, el artículo 4 del tratado dispone que: "Los tribunales de los Estados contratantes, que entren a conocer un litigio relativo a un contrato concluido entre personas de las mencionadas por el artículo 1 y que comporte un compromiso o una cláusula compromisoria válida en virtud de dicho artículo y susceptible de ser aplicada, remitirán a los interesados al juicio de árbitros si así lo solicitare uno de ellos". Protocolo relativo a las cláusulas arbitrales aprobado en Ginebra el 24 de setiembre de 1923. Artículo 4.

9 Protocolo relativo a las cláusulas arbitrales aprobado en Ginebra el 24 de setiembre de 1923. Artículo 2. 
excepción del convenio arbitral, la materia arbitrable, entre otras cuestiones. En palabras del profesor Gary Born:

“The Geneva Protocol played a critical - if often underappreciated - role in the development of the legal framework for international commercial arbitration. Among other things, the Protocol laid the basis for the modern international arbitral process, requiring Contracting States to recognize, if only imperfectly, the enforceability of specified international arbitration agreements and arbitral awards; in particular, the Protocol was limited to arbitration agreements "between parties subject respectively to the jurisdiction of different contracting states." The Protocol also permitted Contracting States to limit its scope to "contracts which are considered as commercial under its national law." 10

Dicha opinión es compartida por los profesores Fouchard, Gaillard y Goldman:

"Although the Protocol is brief, containing only four articles covering the validity and effect of arbitration clauses, it nevertheless had a decisive impact on the future of arbitration throughout the world. In France, the signing of the Protocol, even prior to ratification, prompted the legislature to make arbitration clauses valid in commercial transactions. The Protocol also laid a foundation for the worldwide development of international arbitration, which is obviously dependent on the effectiveness of arbitration agreements in international contracts. It also left the parties free to determine the arbitral procedure (Art. 2) and obliged states and national courts to ensure that arbitration agreements (Art. 4) and the resulting awards (Art. 3) could be enforced." 11

Sin embargo, no todo era color de rosa. En cuanto a reconocimiento de laudos arbitrales extranjeros, coincidimos con Born en que el artículo 3 hacía complicada su aplicación $\mathrm{y}$, por lo tanto, algunos destacados autores consideraron que era un intento incompleto. ${ }^{12}$ Esto porque solo hacía que, en palabras de Gary Born, "providing only for Contracting States to enforce awards made on their own territory (i.e., not "foreign" awards, made in other

10 BORN, Gary. International Commercial Arbitration, 2da edición, Kluwer Law International, 2014, p. 65.

11 GAILLARD, Emmanuel y SAVAGE, John. Fouchard Gaillard Goldman on International Commercial Arbitration, Kluwer Law International, 1999, p. 121.

12 El artículo 3 disponía lo siguiente: “Cada Estado contratante se compromete a asegurar la ejecución por sus autoridades, y de conformidad Con las disposiciones de su ley nacional, de las sentencias arbitrales dictadas en su territorio en virtud de los artículos precedentes". Protocolo relativo a las cláusulas arbitrales aprobado en Ginebra el 24 de setiembre de 1923. De acuerdo a dicho artículo, este Tratado solo regulaba la ejecución de laudos arbitrales dictados en el territorio de dicho Estado y no el reconocimiento de laudos arbitrales extranjeros. 
countries). Even then, enforcement was required only in accordance with local law - effectively making the commitment dependent on each individual state's arbitration legislation. In contrast to the simple, but dramatic, provisions of the Geneva Protocol regarding arbitration agreements, Article III's treatment of arbitral awards was at best tentative and incomplete"13.

\section{ii. Convención de Ginebra}

Cuatro años después de la aprobación del Protocolo de Ginebra, la Liga de Naciones fomentó una nueva convención en materia arbitral. El resultado fue que en 1927 se aprobara la Convención Internacional para la Ejecución de las Sentencias Arbitrales Extranjeras o más conocida como la Convención de Ginebra. ${ }^{14}$

Este tratado regulaba el reconocimiento y ejecución de laudos arbitrales emitidos sobre la base de los convenios arbitrales regulados en el Protocolo de Ginebra de 1923.

La Convención de Ginebra -sin duda- significó un paso adelante respecto del Protocolo de Ginebra, toda vez que regulaba el reconocimiento y ejecución de laudos arbitrales. Sin embargo, al igual que el Protocolo de Ginebra, presentaba diversos problemas en su ámbito de aplicación.

Para que se pueda reconocer un laudo arbitral al amparo de este tratado debía haber sido emitido en un país parte y con personas de Estados parte del mismo. ${ }^{15}$ Como vemos el alcance de la Convención de Ginebra era muy

13 BORN, Gary. International Commercial Arbitration, 2da edición, Kluwer Law International, 2014, p. 66.

14 Convención Internacional para la Ejecución de las Sentencias Arbitrales Extranjeras firmada en Ginebra el 26 de setiembre de 1927. Son estados parte: Alemania, Austria, Bélgica, Congo Belga, Territorio de Ruanda-Urundi, Checoslovaquia, Dinamarca, España, Estonia, Finlandia, Francia, Grecia, India, Irlanda, Israel, Italia, Japón, Luxemburgo, Malta, Mauricio, Nueva Zelandia (incluida Samoa Occidental), Países Bajos, Respecto del Reino en Europa), Respecto de las Indias Neerfandesas, Surinam, y Curacao, Portugal, Reino Unido de Gran Bretaña e Irlanda del Norte, Terranova, Bahamas, Guayana Británica, Honduras Británica, Islas Malvinas (Falkland), Gibraltar, Costa de Oro, d) Togo bajo Mandato británico], Jamaica, (incluidas las Islas Turcas y Caicos y las Islas Caimán), Kenia, Palestina (excluida la Transjordania), Territorio de Tanganyika, Protectorado de Uganda, Islas Windward (Granada, Santa Lucia, San Vicente), Zanzíbar, Mauricio, Rhodesia del Norte, Islas Leeward (Antigua, Dominica, Montserrat, San Cristóbal, Nieves, Islas Vírgenes), Malta, Birmania (excluidos los Estados de Karenni bajo soberanía de Su Majestad), Hong Kong 10 febrero 1965, Rumania 22 junio 1931, Suecia 8 agosto 1929, Suiza 25 septiembre 1930, Tailandia Yugoslavia, Bolivia, Nicaragua, Perú, República de Corea, Uganda.

15 Convención sobre la Ejecución de Sentencias Arbitrales Extranjeras aprobado en Ginebra el 26 de setiembre de 1927.

"Artículo 1. En los territorios dependientes de una de las Altas Partes contratantes, a los cuales se aplique la presente Convención, se reconocerá la autoridad de toda sentencia arbitral recaída como consecuencia de un compromiso o de una cláusula compromisoria, señalados en el Protocolo relativo a las cláusulas de arbitraje, abierto a la firma en Ginebra a partir del 24 de septiembre de 1923, y la ejecución de dicha sentencia se llevará a efecto de 
limitado. Por ello, el profesor van den Berg identifica correctamente que: "their field of application was limited: the parties had to be subject to the jurisdiction of different Contracting States, and the arbitral award should have been made in a Contracting State ${ }^{16 . "}$

Asimismo, la parte que buscaba el reconocimiento y la ejecución del laudo arbitral era la encargada de probar una serie de cuestiones ${ }^{17}$ :

a. Primero, debía acreditar que el convenio arbitral que originó el laudo era válido según la legislación que sea aplicable ${ }^{18}$.

b. Segundo, debía demostrar que, de acuerdo al país donde se solicitaba el reconocimiento, el objeto de la controversia era arbitrable.

c. Tercero, debía probar que el Tribunal Arbitral dictó el laudo dentro de los alcances que le concedieron las partes.

d. Cuarto, la parte que solicitaba el reconocimiento debía probar que el Tribunal Arbitral se había constituido conforme al acuerdo de las partes o al derecho aplicable al procedimiento de arbitraje. Esto traía problemas porque había que indagar los requisitos legales de la sede del arbitraje.

e. Quinto, debía acreditar que el laudo donde fue dictado no era susceptible de impugnación, apelación o casación, o que estaba en procedimiento para impugnar el laudo. Es más, tenía que probar la firmeza del laudo arbitral. Así, el artículo 4 establecía la obligación de demostrar que "los documentos y datos capaces de establecer que la

conformidad con las reglas de procedimiento seguidas en el territorio donde la sentencia se invoque, cuando dicha sentencia haya sido dictada en un territorio dependiente de una de las Altas Partes contratantes al cual se aplique la presente Convención y entre personas sometidas a la jurisdicción de una de las Altas Partes contratantes".

16 VAN DEN BERG, Albert Jan. The New York Convention of 1958. Kluwer Law and Taxation Publishers, La Haya, 1981, p. 7.

17 El artículo 1 de la Convención de Ginebra dispone que "Para obtener dicho reconocimiento o dicha ejecución será necesario además: a) Que la sentencia haya sido dictada a consecuencia de un compromiso o cláusula compromisoria válidos, según la legislación que les sea aplicable. b) Que con arreglo a la Ley del país donde sea invocada, el objeto de la sentencia sea susceptible de solución por vía de arbitraje. c) Que la sentencia haya sido pronunciada por el Tribunal arbitral previsto en el compromiso o en la cláusula compromisoria, o constituido conforme acuerdo de las Partes y a las reglas de derecho aplicables al procedimiento de arbitraje. d) Que la sentencia se haya hecho firme en el país donde hubiere sido dictada, no considerándose como tal si es susceptible de impugnación, apelación o recurso de casación (en los países en que existan dichos procedimientos), o si se prueba que está en curso un procedimiento para impugnar la validez de la sentencia. e) Que el reconocimiento o ejecución de la sentencia no sean contrarios al orden público o a los principios del derecho público en el país en que se invoque". Convención sobre la Ejecución de Sentencias Arbitrales Extranjeras aprobado en Ginebra el 26 de setiembre de 1927. Artículo 1.

18 Incluso no se definía cual era la legislación aplicable para definir la validez del laudo. La Convención de Ginebra simplemente decía "según la legislación que les sea aplicable". 
sentencia se ha hecho firme". A esto se le conoció como el doble exequátur que describiremos más adelante. ${ }^{19}$

Como bien, indica Born, esto generó la mayor parte de dificultades e incertidumbre al momento de aplicar la Convención. ${ }^{20}$

f. Sexto, debía demostrar que el laudo no era contrario al orden público del país donde se solicitaba el reconocimiento.

Tal como se puede observar, dicho tratado establecía una serie de requisitos probatorios para la parte que solicitaba el reconocimiento. De hecho, van den Berg indica que "the Geneva Convention placed upon the party seeking enforcement the heavy burden of proving the conditions necessary for the enforcement." 21 Ello, sin perjuicio de rebatir las defensas que podía esgrimir la parte que se oponía al reconocimiento ${ }^{22}$ y que cada Estado podía añadir causales para denegar el reconocimiento. ${ }^{23}$

De este modo, no hay dudas que bajo la Convención de Ginebra era

19 Al respecto, van den Berg sostiene que: "One of these conditions was that the award had to become "final" in the country where it was made ("country of origin"). Many courts interpreted this condition as requiring a leave for enforcement (exequátur or the like) from the court of the country of origin. Since in the country where enforcement was sought a leave for enforcement was also needed, this interpretation amounted in practice to the system of the so-called "double-exequatur". VAN DEN BERG, Albert Jan. The New York Convention of 1958. Kluwer Law and Taxation Publishers, La Haya, 1981, p. 7.

20 BORN, Gary. International Commercial Arbitration, 2da edición, Kluwer Law International, 2014, p. 67: "The Convention also required the award-creditor to show that the award had become "final" in the place of arbitration and was not contrary to the public policy of the recognizing state. This approach to the awards' finality led to the so-called "double exequatur" requirement - whereby an award could effectively only be recognized abroad under the Geneva Convention if it had been confirmed by the courts of the place of the arbitration. This proved a major source of difficulty and uncertainty in establishing the finality of international arbitral awards under the Geneva Convention".

21 VAN DEN BERG, Albert Jan. The New York Convention of 1958. Kluwer Law and Taxation Publishers, La Haya, 1981, p. 7.

22 Convención sobre la Ejecución de Sentencias Arbitrales Extranjeras aprobado en Ginebra el 26 de setiembre de 1927. Artículo 2.

"Aun en el caso de que concurran las condiciones previstas en el artículo 1 no se procederá al reconocimiento y ejecución de la sentencia si el Juez comprobare: a) Que la sentencia ha sido anulada en el país donde fue dictada. b) Que la Parte contra la cual la sentencia se invoque no ha tenido conocimiento, en tiempo oportuno, del procedimiento de arbitraje para hacer valer sus medios, o que siendo incapaz, no haya estado regularmente representada. c) Que la sentencia no verse sobre la diferencia prevista en el compromiso, o no se encuentre incluida en las previsiones de la cláusula compromisoria, o que contenga decisiones que excedan de los términos del compromiso o de la cláusula compromisoria".

23 Convención sobre la Ejecución de Sentencias Arbitrales Extranjeras aprobado en Ginebra el 26 de setiembre de 1927. Artículo 3.

"Si la Parte contra la que ha sido dictada la sentencia acreditare que, de conformidad con las reglas de derecho aplicables al procedimiento de arbitraje, existe una causa distinta de las señaladas en el artículo 1, letras a) y c), y el artículo 2, letras b) y c), que le permite impugnar en justicia la validez de la sentencia, el Juez, si lo estima oportuno, podrá no proceder al reconocimiento o a la ejecución de la misma, o suspenderlos, dando a la Parte un plazo razonable para que sea declarada la nulidad por el Tribunal competente". 
sumamente complicado conseguir el reconocimiento y ejecución de un laudo arbitral extranjero por (i) el ámbito de aplicación de este Tratado, (ii) la carga de la prueba que recaía en el demandante y (iii) las defensas que podían ser alegadas por la parte que se oponía al reconocimiento.

\section{iii. Propuesta CCI}

Tras la Segunda Guerra Mundial, el incremento del comercio internacional y los problemas que generaba la Convención de Ginebra (que no había sido ratificada por las potencias vencedoras de la Segunda Guerra Mundial: Estados Unidos y la Unión Soviética), la CCI publicó un proyecto de convención aplicable al reconocimiento y ejecución de laudos que fue catalogado como bastante liberal. ${ }^{24}$

De hecho, este modelo de convención establecía que el arbitraje no debía estar gobernado por ningún sistema de derecho nacional ya que se tenía la noción de un laudo arbitral verdaderamente internacional. Según refiere Sanders el mencionado proyecto era muy progresista para estos tiempos. ${ }^{25}$

Sin embargo, en el contexto de dicho proyecto, el Consejo Económico y Social de las Naciones Unidas (en adelante, “ECOSOC") elaboró en 1955 un proyecto de convención mucho más similar al de la Convención de Ginebra.

Como indica van den Berg, mientras que el proyecto de convención elaborada por ECOSOC se refería a "laudos arbitrales extranjeros", el proyecto de la CCI se refería a "laudos arbitrales internacionales." 26 Esta propuesta fue enviada a los gobiernos y organizaciones internacionales y no gubernamentales internacionales para comentarios. En base a ello, se llevó a cabo una Conferencia en los Cuarteles Generales de las Naciones Unidas que resultó en la adopción de la Convención de Nueva York. ${ }^{27}$

24 GAILLARD, Emmanuel y SAVAGE, John. Fouchard Gaillard Goldman on International Commercial Arbitration. Kluwer Law International, 1999, p. 122.

Ver también VAN DEN BERG, Albert Jan. The New York Convention of 1958. Kluwer Law and Taxation Publishers, La Haya, 1981, p. 7.

25 SANDERS, Pieter. "The History of the New York Convention". En Improving the Efficiency of Arbitration Agreements and Awards: 40 Years of Application of the New York Convention, ICCA Congress Series Volume 9, van den Berg, Albert Jan (ed.), Kluwer Law International, 1999, p. 11.

26 VAN DEN BERG, Albert Jan. The New York Convention of 1958. Kluwer Law and Taxation Publishers, La Haya, 1981, pp. 7-8.

Ver también SANDERS, Pieter. "The History of the New York Convention". En Improving the Efficiency of Arbitration Agreements and Awards: 40 Years of Application of the New York Convention, ICCA Congress Series Volume 9, van den Berg, Albert Jan (ed.), Kluwer Law International, 1999, p. 11.

27 VAN DEN BERG, Albert Jan. The New York Convention of 1958. Kluwer Law and Taxation Publishers, La Haya, 1981, p. 8. 


\section{iv. Adopción de la Convención de Nueva York}

Esta Convención ha sido aprobada a la fecha por 157 Estados y es considerada uno de los hitos más importantes del arbitraje comercial internacional. ${ }^{28}$ No en vano, van den Berg sostiene que la Convención de Nueva York es "the cornerstone of current international commercial arbitration"29; o Lord Mustill indica que "this Convention has been the most successful international instrument in the field of arbitration, and perhaps could lay claim to be the most effective instance of international legislation in the entire history of commercial law" 30 .

Asimismo, Stephen Schwebel sostiene que “(...) the New York Convention works. For the most part it works well. Foreign arbitral awards are regularly recognized and enforced the world over. Awards are paid, if necessary with the assistance of local courts" 31 .

Como bien indica Gary Born, “(g)enerally referred to as the 'New York Convention' the treaty is by far the most significant contemporary legislative instrument relating to international commercial arbitration. It provides what amounts to a universal constitutional charter for the international arbitral

28 Al 22 de octubre de 2017, los siguientes 157 Estados son miembros de la Convención de Nueva York: Afganistán, Albania, Alemania, Andorra, Angola, Antigua y Barbuda, Arabia Saudita, Argelia, Argentina, Armenia, Australia, Austria, Azerbaiyán, Bahamas, Bahrein, Bangladesh, Barbados, Belarús, Bélgica, Benin, Bhután, Bolivia (Estado Plurinacional de), Bosnia y Herzegovina, Botswana, Brasil, Brunei Darussalam, Bulgaria, Burkina Faso, Burundi, Camboya, Camerún, Canadá, Chile, China, Chipre, Colombia, Comoras, Costa Rica, Côte d'Ivoire, Croacia, Cuba, Dinamarca, Djibouti, Dominica, Ecuador, Egipto, El Salvador, Emiratos Árabes Unidos, Eslovaquia, Eslovenia, España, Estado de Palestina, Estados Unidos de América, Estonia, Federación de Rusia, Fiji, Filipinas, Finlandia, Francia, Gabón, Georgia, Ghana, Grecia, Guatemala, Guinea, Guyana, Haití, Honduras, Hungría, India, Indonesia, Irán (República Islámica del), Irlanda, Islandia, Islas Cook, Islas Marshall, Israel, Italia, Jamaica, Japón, Jordania, Kazajstán, Kenya, Kirguistán, Kuwait, La ex República Yugoslava de Macedonia, Lesotho, Letonia, Líbano, Liberia, Liechtenstein, Lituania, Luxemburgo, Madagascar, Malasia, Malí, Malta, Marruecos, Mauricio, Mauritania, México, Mónaco, Mongolia, Montenegro, Mozambique, Myanmar, Nepal, Nicaragua, Níger, Nigeria, Noruega, Nueva Zelandia, Omán, Países Bajos, Pakistán, Panamá, Paraguay, Perú, Polonia, Portugal, Qatar, Reino Unido de Gran Bretaña e Irlanda del Norte, República Árabe Siria, República Centroafricana, República Checa, República de Corea, República de Moldova, República Democrática del Congo, República Democrática Popular Lao, República Dominicana, República Unida de Tanzanía, Rumania, Rwanda, San Marino, Santa Sede, Santo Tomé y Príncipe, San Vicente y las Granadinas, Senegal, Serbia, Singapur, Sri Lanka, Sudáfrica, Suecia, Suiza, Tailandia, Tayikistán, Trinidad y Tabago, Túnez, Turquía, Ucrania, Uganda, Uruguay, Uzbekistán, Venezuela (República Bolivariana de), Vietnam, Zambia, Zimbabwe.

29 Van den Berg, Albert Jan. The New York Convention of 1958. Kluwer Law and Taxation Publishers, La Haya, 1981, p. 1.

30 LORD MUSTILL, Michael. “Arbitration: History and Background”. En JIA, Vol. 6, No. 2, 1989 , p. 49.

31 SCHWEBEL, Stephen M. "A Celebration of the United Nations New York Convention on the Recognition and Enforcement of Foreign Arbitral Awards". En Arb. Int., Vol. 12, No. 1, Kluwer Law International, 1996, pp. 88-89. 
process, whose sweeping terms have enabled both national courts and arbitral tribunals to develop durable, effective means for enforcing international arbitration agreements and arbitral awards. The Convention also provided the basis for most contemporary national legislation governing the international arbitral process, and in particular the UNCITRAL Model Law, which has implemented and elaborated upon the Convention's basic principles and legal framework"32.

Por último, Philippe Fouchard afirmó que: “(t)he New York Convention certainly played an essential role in the progress achieved for the international "circulation" of awards, either by imposing such progress or by allowing that others may be achieved without $i^{\prime \prime} 33$. El recordado árbitro francés indica que a 1999, bajo la Convención de Nueva York el 90\% de los laudos se lograban reconocer. 34

¿Qué fue lo que hizo la Convención de Nueva York para que sea tan reconocida? En primer lugar, corrigió los problemas de los tratados existentes a la fecha: el Protocolo de Ginebra y la Convención de Ginebra. En efecto, como bien resume Sanders:

"The main elements of the "Dutch proposal" were, first of all, the elimination of the double exequatur, one in the country where the award was made and another one in the country of the enforcement of the award. Under the Geneva Convention we always requested both. It is logical to require an exequatur only in the country where enforcement of the award is sought and not in the country where the award is made but no enforcement is sought. I remember that the disappearance of the double exequatur was so warmly welcomed during the Conference that the suggestion was made to create a new cocktail: the "double exequatur". Another element of the proposal was to restrict the grounds for refusal of recognition and enforcement as much as possible and to switch the burden of proof of the existence of one

32 Born, Gary. International Commercial Arbitration. 2da Edición, Kluwer Law International, 2014, p. 99.

33 FOUCHARD, Philippe. "Suggestions to Improve the International Efficacy of Arbitral Awards". En Improving the Efficiency of Arbitration Agreements and Awards: 40 Years of Application of the New York Convention, ICCA Congress Series Volume 9, van den Berg, Albert Jan (ed.), Kluwer Law International, 1999, p. 602.

34 Philippe Fouchard revela que: "Have we not already made significant progress, specifically with the New York Convention and since its signature? Figures were quoted: more than 90\% of the court decisions published in the Yearbook Commercial Arbitration allow the enforcement of international arbitral awards. Should more be done? Should one aim for $100 \%$ ? FOUCHARD, Philippe. "Suggestions to Improve the International Efficacy of Arbitral Awards". En Improving the Efficiency of Arbitration Agreements and Awards: 40 Years of Application of the New York Convention, ICCA Congress Series Volume 9, van den Berg, Albert Jan (ed.), Kluwer Law International, 1999, p. 602. A la fecha, no se han encontrado datos exactos más actualizados. 
or more of these grounds to the party against whom the enforcement was sought. This again stands to reason because the grounds for refusal deal with exceptional cases. Logically, these grounds should be invoked by the party who opposes the exequatur. All of this is reflected in Art. V, the heart of the Convention" 35 .

Veamos pues a continuación cuáles son los principales elementos de la Convención de Nueva York, aquellos que precisamente la han llevado a ser tan exitosa.

\section{Regulación de la Convención de Nueva York}

\section{i. Ámbito de aplicación amplio y universal}

La principal característica de la Convención de Nueva York es su ámbito de aplicación amplio y de alcance universal. ${ }^{36}$ Este tratado se aplica al reconocimiento y ejecución de laudos arbitrales dictados en un territorio distinto de aquel del cual se solicita el reconocimiento. ${ }^{37}$ Así, el artículo I de la referida convención dispone lo siguiente:

"La presente Convención se aplicará al reconocimiento y la ejecución de las sentencias arbitrales dictadas en el territorio de un Estado distinto de aquel en que se pide el reconocimiento y la ejecución de dichas sentencias, y que tengan su origen en diferencias entre personas naturales o jurídicas" 38 .

Como fluye de su texto, basta con que la sentencia haya sido dictada en un territorio distinto del que se solicita el reconocimiento para que se pueda reconocer un laudo arbitral ${ }^{39}$. En ese sentido, para que un laudo sea susceptible

35 SANDERS, Pieter. "The History of the New York Convention". En Improving the Efficiency of Arbitration Agreements and Awards: 40 Years of Application of the New York Convention, ICCA Congress Series Volume 9, van den Berg, Albert Jan (ed.), Kluwer Law International, 1999, p. 12.

36 Van den Berg, Albert Jan. The New York Convention of 1958, Kluwer Law and Taxation Publishers, La Haya, 1981, p. 1.

37 En la Introducción de la Convención de Nueva York se establece, "En el momento de firmar o de ratificar la presente Convención, de adherirse a ella o de hacer la notificación de su extensión prevista en el artículo $X$, todo Estado podrá, a base de reciprocidad, declarar que aplicará la presente Convención al reconocimiento y a la ejecución de las sentencias arbitrales dictadas en el territorio de otro Estado Contratante únicamente." Convención de Nueva York.

38 Convención de Nueva York. Artículo 1.

39 Esto sin perjuicio que la Convención de Nueva York también se aplica al reconocimiento de laudos arbitrales dictados en el territorio que sean considerados como laudos arbitrales no nacionales. El Artículo I(2) de la Convención de Nueva York dispone que: "La expresión "sentencia arbitral" no sólo comprenderá las sentencias dictadas por los árbitros nombrados para casos determinados, sino también las sentencias dictadas por los órganos arbitrales permanentes a los que las partes se hayan sometido." Convención de Nueva York. 
de reconocimiento debe ser extranjero, es decir, debe haber sido dictado en un territorio distinto de aquel del que se pide el reconocimiento. Así, como indica van den Berg:

"The title of the Convention refers to the recognition and enforcement of foreign arbitral awards". What is understood by a foreign award can be found in Article I(1): an arbitral award made in the territory of a State other than the State where the recognition and enforcement of such award is sought. As no other condition is required, the scope of the Convention is very broad: an award made in any foreign country, whether in a Contracting State or not, falls under the New York Convention. Such a definition of the field of application can be said to be the modern tendency in international conventions. Traditionally, international conventions were conceived to regulate relations between Contracting States only. This was the case under the Geneva Convention of 1927, which required that the award be made in one of the Contracting States between persons who are subject to their jurisdiction. A more modern approach, as laid down in the first paragraph of Article I of the New York Convention, is to consider international conventions as the consensus on the state of international law public or private - in a certain field" 40.

La Convención de Nueva York no establece que el laudo arbitral debe ser internacional. Simplemente, que sea un laudo. De esta manera, no se siguió la propuesta de la CCI. Así, los profesores Fouchard, Gaillard y Goldman señalan que:

"The application of the New York Convention is not restricted to international arbitration. The text contains no "internationality" requirement. The concept of a "foreign" award, as mentioned in the title of the Convention, still suggests a national connection. Article I of the Convention provides that, in principle, a "foreign" award is an award made in a country other than that in which its recognition and enforcement are sought. Whether the dispute involves the interests of international trade is irrelevant. So too is whether the arbitration has one or more foreign components. In order for the Convention to apply in a contracting state, all that is necessary, in principle is that the award in question be made in another country. The award may have been made in a purely domestic dispute following an arbitration in which all elements

Ver también VAN DEN BERG, Albert Jan. "The New York Convention of 1958: An Overview". En Enforcement of Arbitration Agreements and International Arbitral Awards: The New York Convention in Practice, Gaillard, Emmanuel y Di Pietro, Domenico (eds.), Cameron May, 2008, p. 40.

40 VAN DEN BERG, Albert Jan. The New York Convention of 195., Kluwer Law and Taxation Publishers, La Haya, 1981, p. 12. 
were connected to that one country. The arbitration would then be national, but the award becomes foreign when enforcement is sought outside the country where it was made" 41 .

En el mismo sentido se pronuncia van den Berg.42 Así pues, basta con que sea un laudo dictado en un territorio distinto de aquel que se solicite el reconocimiento para que se pueda reconocer al amparo de la Convención de Nueva York.

Por ejemplo, si un laudo que involucra a las partes X e Y se dicta en Alemania y se pretende reconocer en Jamaica, lo relevante será determinar si Jamaica es parte de la Convención de Nueva York para ver si este tratado se aplica al caso concreto. No será relevante determinar si bajo la legislación jamaiquina o alemana ese laudo es internacional. Es solo importante si el laudo se pretende reconocer en un Estado parte de la Convención.

Como es claro, esto favorece el reconocimiento de los laudos arbitrales puesto que elimina cualquier criterio que el laudo sea internacional con lo difícil e indeterminado que es definir este concepto.

Ahora bien, la propia Convención de Nueva York dispone que se encontrarán dentro de su ámbito de aplicación aquellas "sentencias arbitrales que no sean consideradas como sentencias nacionales en el Estado en el que se pide su reconocimiento y ejecución"43.

En ese sentido, será relevante lo que establezca la ley del lugar donde se solicita el reconocimiento, pues será la ley del Estado del exequátur la que defina si el laudo califica como uno no doméstico y serán los tribunales de dicho Estado los que finalmente determinen si califica como un laudo no doméstico al amparo de lo previsto en su legislación. ${ }^{4}$

41 GAILLARD, Emmanuel y SAVAGE, John. Fouchard Gaillard Goldman on International Commercial Arbitration, Kluwer Law International, 1999, p. 126.

42 VAN DEN BERG, Albert Jan. The New York Convention of 1958. Kluwer Law and Taxation Publishers, La Haya, 1981, p. 17. "The definition of a foreign award as "an award made in the territory of another (Contracting) State' has as consequence that in theory the Convention also applies to an award made in a foreign country in respect of a matter which is purely domestic for the country where the award was made. Thus, in Switzerland the enforcement of an award made in Paris in a dispute between a merchant from Bordeaux and a retailer in Nice concerning the sale of bottles of French wine will fall under the New York Convention. Although the Convention is primarily intended to facilitate arbitration in international commerce, it does not contain any indication that the underlying transaction should be international."

43 Convención de Nueva York. Artículo I.

44 PAULSSON, Marike R.P. The 1958 New York Convention in Action. Kluwer Law International, 2016, pp. 101 - 102. "The category of "non-domestic awards" was a compromise. Proponents of the straight-forward notion of "foreign" awards were looking at the matter from a purely territorial point of view, but some delegates found it important, for the future acceptability of the Convention for prospective Contracting States, that the "nationality" of an award retain 
Sin perjuicio de ello, la Convención de Nueva York permite que los Estados solo reconozcan laudos arbitrales dictados en el territorio de un Estado parte de la Convención de Nueva York, pero para ello deberán formular al momento de adherirse a la misma la reserva de reciprocidad, que es la excepción a la regla general.

Por ejemplo, si el Estado $\mathrm{X}$ desea que solo se reconozcan laudos arbitrales dictados en un país parte de la Convención de Nueva York, entonces deberá formular expresamente la reserva de reciprocidad. En esa línea, al momento de reconocer un laudo arbitral en el Estado $X$ se deberá identificar si el laudo arbitral proviene de un Estado parte de la Convención de Nueva York. En este ejemplo ficticio, si el laudo proviene de Perú que es parte de la Convención de Nueva York, entonces el laudo será reconocido en el Estado X. Por el contrario, si el laudo ha sido dictado en Belize, que no es parte de la Convención de Nueva York, entonces no se podrá reconocer en el Estado X.

Como bien indica van den Berg, el uso de esta reserva hoy en día tiene poco impacto en la aplicación de la Convención de Nueva York debido al incremento del número de Estados parte. ${ }^{45}$ La posibilidad de que se lleve a reconocer un laudo que provenga de un Estado que no sea parte de la Convención de Nueva York a un Estado que sea parte de la Convención de Nueva York y haya formulado la reserva de posibilidad, son bajas.

Asimismo, la Convención de Nueva York no restringe su aplicación a laudos arbitrales comerciales. Tal como está redactado el tratado, se permite que los Estados reconozcan laudos arbitrales extranjeros comerciales o no. Sin perjuicio de ello, la Convención de Nueva York permite que los Estados reconozcan solamente laudos arbitrales comerciales. ${ }^{46}$ Para ello, el Estado que quiera formular esta reserva comercial deberá decirlo al momento de adherirse. ${ }^{47}$ Sin embargo, esta reserva ha perdido su importancia al haber sido

some meaning in the sense that national courts might deem an award not to fall under the local law even though rendered in their jurisdiction if it presents sufficient elements of "internationality" - and thus be accepted as falling under the new treaty. The problem lies in defining the concept of non-domestic awards, left to be sorted out by enforcement courts."

45 VAN DEN BERG, Albert Jan. The New York Convention of 1958. Kluwer Law and Taxation Publishers, La Haya, 1981, p. 13.

46 Convención de Nueva York. Artículo I.3. "En el momento de firmar o de ratificar la presente Convención, de adherirse a ella o de hacer la notificación de su extensión prevista en el artículo X, todo Estado podrá, a base de reciprocidad, declarar que aplicará la presente Convención al reconocimiento y a la ejecución de las sentencias arbitrales dictadas en el territorio de otro Estado Contratante únicamente."

47 Entre los Estados que se han adherido a la Convención de Nueva York con la reserva comercial están: Afganistán, Antigua y Barbuda, Argelia, Argentina, Armenia, Bahrein, Barbados, Bhután, Bosnia y Herzegovina, Botswana, Burundi, China, Chipre, Croacia, Cuba, Dinamarca, Djibouti, Ecuador, Estados Unidos de América, Filipinas, Grecia, Guatemala, Honduras, Hungría, India, Indonesia, Irán, Jamaica, La ex República Yugoslava de 
interpretada de manera amplia y contemplando una variedad de supuestos. 48

Por otro lado, debemos destacar que la Convención de Nueva York no restringe su ámbito de aplicación a partes de Estados miembros del tratado. Esto lo diferencia sustancialmente de la Convención de Ginebra que solo era aplicable a casos en los cuales las partes del laudo sean nacionales de o domiciliadas en Estados miembros de la Convención de Ginebra. Así, los profesores Fouchard, Gaillard y Goldman acertadamente han afirmado que:

"The scope of the New York Convention is not limited by reference to the nationality of the parties to the arbitration agreement or the award. This constitutes significant progress as compared to the

Macedonia, Madagascar, Malasia, Mónaco, Mongolia, Montenegro, Nepal, Nigeria, Polonia, República Centroafricana, República de Corea, Rumania, Santa Sede, San Vicente y las Granadinas, Serbia, Trinidad y Tabago, Túnez, Turquía, Venezuela, Vietnam.

Perú se ha adherido a la Convención de Nueva York y no ha formulado la reserva comercial.

48 En efecto, Born indica que: "Even in Contracting States that have adopted a commercial reservation, national courts have generally not construed the "commercial" relationship requirement to limit the scope of the Convention. That is particularly true in the United States, where courts have repeatedly rejected arguments that particular disputes are not "commercial" within the meaning of the Convention. Several lower U.S. courts have indicated that the definition of "commercial" under the Convention is broader than that of "commerce" under the domestic FAA.

U.S. courts have, unsurprisingly, held that a "classic" example of a commercial relationship is one "involving the purchase and sale of goods by two corporations." Additionally, it is clear in the United States that the term "commercial relationship" includes employeeemployer relations, consumer transactions, shareholder disputes, contracts where a foreign state constructs buildings for (and leases them to) a foreign investor, relationships giving rise to antitrust and other public law disputes, cases involving claims by foreign regulatory authorities, insurance and reinsurance contracts and maritime agreements. Emphasizing the breadth of "commercial" activities, one U.S. court held that "[t]he fact that the employeremployee relationship may include a degree of fiduciary obligation does not deprive it of its commercial character."

U.S. courts have also concluded that neither the U.S. "commercial" reservation to the Convention nor the Convention and its U.S. implementing legislation, limit the scope of the Convention in U.S. courts to those relationships which are subject to the domestic FAA. Thus, U.S. courts have held that arbitration agreements in seamen's employment contracts, which are specifically excluded from the scope of the domestic FAA, are nonetheless subject to the New York Convention and the FAA's second chapter. As one court reasoned: "the language of the Convention, the ratifying language, and the [FAA's second chapter] implementing the Convention do not recognize an exception for seamen employment contracts. On the contrary, they recognize that the only limitation on the type of legal relationship falling under the Convention is that it must be considered 'commercial' and we conclude that an employment contract is commercial."

The court also concluded that, even if there were questions as to the correctness of this conclusion, "doubts as to whether a contract falls under the [Convention and its implementing legislation] should be resolved in favor of arbitration."

Courts from other developed jurisdictions have also generally interpreted the "commercial" relationship requirement very broadly. Indeed, most reported cases have raised no serious questions as to the scope of the requirement. In Carters (Merchants) Ltd v. Ferraro, for example, an Italian court held that the arbitration clauses contained in the parties' contract fell within the New York Convention. The court noted that the clauses referred exclusively to a contractual relationship involving a sale, which was plainly "commercial" under Italian law." BORN, Gary. International Commercial Arbitration, 2da edición, Kluwer Law International, 2014, pp. 299-301. 
1927 Convention, which applied only where the parties were "subject to the jurisdiction of one of the high contracting parties"." 49 .

En el mismo sentido, el profesor van den Berg agrega que:

"The field of application of the Convention does not depend on the nationality of the parties. Such a condition was contained in the Geneva Convention of 1924, which required that the parties be subject to the jurisdiction of different Contracting States. The expression "subject to the jurisdiction" of a State had caused uncertainty, as some courts interpreted it as meaning nationality, whilst others considered it as domicile. Moreover, as a consequence of the awakening principle of universality, there was no longer any reason to make a Convention in favor of subjects of a particular State only. Having omitted the condition, the New York Convention is broader and clearer in its scope than its predecessor" 50 .

Como vemos, el ámbito de aplicación de la Convención de Nueva York es favorable para el arbitraje toda vez que no tiene mayores candados para su aplicación. Basta con que el laudo se dicte en un territorio distinto del que se pide el reconocimiento para que el mismo se pueda reconocer.

No existen limitaciones de nacionalidad o internacionalidad del laudo que sean aplicables. El carácter pro-arbitraje está marcado en diversas disposiciones del Tratado destinadas a favorecer y facilitar el reconocimiento de laudos arbitrales extranjeros. A continuación, continuaremos desarrollando las más valiosas características de la Convención de Nueva York.

\section{ii. Facilitar el comercio internacional y favorecer el reconocimiento de laudos arbitrales extranjeros}

Como vimos antes, la Convención de Nueva York tiene como particular interés solucionar las necesidades del comercio internacional y promover el régimen legal establecido en el Protocolo de Ginebra y la Convención de Ginebra51. Por ello, los profesores Fouchard, Gaillard y Goldman afirman que:

49 GAILLARD, Emmanuel y SAVAGE, John. Fouchard Gaillard Goldman on International Commercial Arbitration. Kluwer Law International, 1999, p. 125.

50 VAN DEN BERG, Albert Jan. The New York Convention of 1958. Kluwer Law and Taxation Publishers, La Haya, 1981, p. 15.

51 BORN, Gary. International Commercial Arbitration, 2da edición, Kluwer Law International, 2014, p. 100. “The Convention was adopted - like many national arbitration statutes specifically to address the needs of the international business community and international trade and commerce. In particular, the Convention was intended to improve the legal regime provided by the Geneva Protocol and Geneva Convention for the international arbitral process." 
"Following World War II and the subsequent growth of international trade, the weaknesses of the 1927 Geneva Convention, which neither the United States nor the Soviet Union had ratified, became very apparent. It needed to be revised if arbitration was to become an efficient means of resolving international disputes" 52 .

Del mismo modo, Laurence Craig sostiene que:

"The growth of international commercial arbitration is largely a post-World War II phenomenon, fueled by the explosive growth of international trade and commerce and foreign investment in both developing and developed countries. While trade and investment were becoming increasingly transnational, and the multinational corporation was developing with an interest in promoting business and profits without regard to national boundaries, national courts, at least from the foreign trader's or investor's point of view, remained resolutely local in outlook (...).

The absence of any multilateral convention for the recognition of foreign judgments, and the existence of very few bilateral treaties with such provisions, makes the arbitral solution not only attractive but compelling. This is due to the existence of an international mechanism for the enforcement of foreign arbitral awards. (...)

In the absence of any international court for the resolution of private international disputes, arbitration has provided the participants in international commerce with a decision-making process which, if not international in the legal sense, is a least internationalized, and which leads to an award, which will ordinarily be enforceable internationally. It is for this reason that commercial arbitration is much more common in international dispute resolution than in domestic dispute resolution" 53 .

Es claro que la Convención de Nueva York busca fomentar el comercio internacional y el flujo de las inversiones. Así, la Convención de Nueva York entiende que el arbitraje es el mejor foro para que estas controversias comerciales se resuelvan. Por ello, este tratado busca proteger el arbitraje comercial internacional y la decisión que adopten los árbitros debe ser respetada.

52 GAILLARD, Emmanuel y SAVAGE, John. Fouchard Gaillard Goldman on International Commercial Arbitration. Kluwer Law International, 1999, p. 122.

53 CRAIG, Laurence. "Some Trends and Developments in the Laws and Practice of International Commercial Arbitration". En Texas International Law Journal, Vol. 30, University of Texas at Austin School of Law Publications, Inc., 1995, pp. 3-4. 
Por consiguiente, la Convención de Nueva York busca que los laudos arbitrales que son dictados en un determinado país puedan ser reconocidos fácilmente en otro Estado. No en vano, un gran número de autoridades han sostenido acertadamente que la Convención de Nueva York tiene un sesgo a favor del reconocimiento.

Como bien indica Gary Born, tanto en jurisdicciones del common law como del civil law, entre las que se encuentran Estados Unidos, Inglaterra, Canadá, Irlanda, Singapur, Hong-Kong, India, Australia, Alemania, Francia, Suiza, Italia, Holanda entre otras, han confirmado que la Convención de Nueva York debe ser interpretada a favor del reconocimiento ${ }^{54}$.

De hecho, en palabras de una decisión de reconocimiento de una corte italiana: "la Convención de Nueva York claramente tiene como objetivo hacer más fácil la ejecución de los laudos arbitrales extranjeros" 55 . En esa misma línea, la Corte de Apelaciones de Inglaterra ha precisado que: "el propósito de la Convención de Nueva York es asegurar el reconocimiento rápido y efectivo de los laudos arbitrales internacionales"56. Por su parte, la Corte Superior de Singapur ha señalado en una decisión de reconocimiento que: "existe el principio de cortesía internacional consagrado en la Convención que se inclina fuertemente a que las cortes den efecto legal a los laudos arbitrales extranjeros" ${ }^{\prime \prime}$.

Así, no hay dudas que la Convención de Nueva York busca facilitar e incrementar el comercio internacional y esto se logra reconociendo más fácilmente los laudos arbitrales extranjeros. El sesgo pro-reconocimiento forma parte del ADN de este tratado.

\section{iii. Eliminación del doble exequátur}

54 BORN, Gary. International Commercial Arbitration. 2da edición, Kluwer Law International, 2014, pp. 3414-3415.

55 Corte de Apelaciones de Florencia, Holzindustrie Schweighofer GmbH v. Industria Legnami Trentina - ILET srl, 3 de junio de 1988. En: YBK 1990 Vol. XV, van den Berg, Albert Jan (ed.), Kluwer Law International, 1990, pp. 498-500, \5. “The New York Convention clearly aimed at making the enforcement of foreign arbitral awards easier" (Traducción libre).

56 Corte Superior de Justicia, Queen's Bench Division (Commercial Court), Nigerian National Petroleum Corporation v. IPCO Limited, 17 de abril de 2008. En: YBK 2008 Volume XXXIII, van den Berg, Albert Jan (ed.), Kluwer Law International, 2008, pp. 788-802, \ 32.

"So do the Convention and the 1996 Act prevent part enforcement of an award in a case such as this as Counsel for NNPC contends? I start by thinking this is unlikely because the purpose of the Convention is to ensure the effective and speedy enforcement of international arbitration awards. (...)." (Traducción libre).

57 Corte Superior de Singapur, Aloe Vera of Am. Inc. v. Asianic Food (S) Pte Ltd, 10 de mayo de 2006. Disponible en: http://www.singaporelaw.sg/sglaw/images/ArbitrationCases/[2006]_3_SLR(R)_0174.pdf Consulta realizada el día 4 de marzo de 2016, p. 40. 
La Convención de Nueva York eliminó el sistema del doble exequátur que existía bajo la Convención de Ginebra. Según este último tratado, para que un laudo pudiera ser reconocido se debía probar que el laudo era firme. Esto fue entendido por las cortes como que el laudo sea ejecutado en la sede del arbitraje. ${ }^{58}$

Bajo la Convención de Ginebra, una vez ejecutado el laudo recién se podía reconocer en otro Estado. Como vemos, la parte que quería cobrar lo ordenado en el laudo tenía que pasar por un engorroso proceso en la sede del arbitraje derrochando tiempo y recursos para que recién se pueda iniciar un proceso de reconocimiento en otro territorio. La Convención de Nueva York no exige que el laudo deba ser ejecutado en la sede del arbitraje para que luego deba ser reconocido en otro país. 59 Una vez emitido el laudo, este ya se puede reconocer en otro Estado. 60

Como bien indica Pieter Sanders, redactor de la Convención de Nueva York:

"The main elements of the "Dutch proposal" were, first of all, the elimination of the double exequatur, one in the country where the award was made and another one in the country of the enforcement of the award. Under the Geneva Convention we always requested both. It is logical to require an exequatur only in the country where enforcement of the award is sought and not in the country where the award is made but no enforcement is sought. I remember that the disappearance of the double exequatur was so warmly welcomed

58 VAN DEN BERG, Albert Jan. The New York Convention of 1958. Kluwer Law and Taxation Publishers, La Haya, 1981, p. 7. "The Geneva Convention placed upon the party seeking enforcement the heavy burden of proving the conditions necessary for the enforcement. One of these conditions was that the award had to become "final" in the country where it was made ("country of origin"). Many courts interpreted this condition as requiring a leave for enforcement (exequatur or the like) from the court of the country of origin. Since in the country where enforcement was sought a leave for enforcement was also needed, this interpretation amounted in practice to the system of the so-called "double-exequatur"."

59 BORN, Gary. International Commercial Arbitration. 2da edición, Kluwer Law International, 2014, p. 124. "It is no longer necessary that the award should be "final" in its country of origin; the award must simply be "binding." Although that term may create difficulties of interpretation in some countries, the existence of an action to set aside no longer prevents enforcement abroad, and a "double exequatur," in the country of origin as well as in the country of enforcement, is no longer necessary."

60 Como veremos más adelante, la Convención de Nueva York (artículo VI) permite a la corte de donde se pretende reconocer el laudo, que difiera el pronunciamiento hasta que termine el proceso de anulación en la sede del arbitraje: “Artículo VI. Si se ha pedido a la autoridad competente prevista en el artículo $\mathrm{V}$, párrafo 1 e), la anulación o la suspensión de la sentencia, la autoridad ante la cual se invoca dicha sentencia podrá, si lo considera procedente, aplazar la decisión sobre la ejecución de la sentencia y, a instancia de la parte que pida la ejecución, podrá también ordenar a la otra parte que dé garantías". Convención de Nueva York. Artículo VI. 
during the Conference that the suggestion was made to create a new cocktail: the "double exequatur"."61.

En efecto, van den Berg acertadamente señala que:

"Another improvement in comparison with the Geneva Convention is the abolishment of the "double exequatur'. The drafters of the New York Convention effected this by providing that the award must be "binding" on the parties, avoiding the more demanding term "final" as used in the Geneva Convention" 62 .

Esto también, ha sido confirmado por las cortes que han aplicado la Convención de Nueva York. Así, por ejemplo, el Tribunal Federal Suizo ha determinado que:

"(T)he aim of the New York Convention is to avoid the double exequatur as was in practice required under the Geneva Convention, although the latter Convention did not require it expressly. Under the New York Convention, it is not necessary to obtain a declaration of enforcement of the award from the court in the country under the law of which the arbitral procedure has taken place" 63 .

Del mismo modo, en un representativo fallo de una corte holandesa se menciona que:

"An important improvement of the New York Convention in comparison with the Geneva Convention (...) is the fact that the double exequatur (leave for enforcement) is abolished. Under the Geneva Convention of 1927, the double exequatur is indispensable because of the requirement that proof be given that means of recourse are no longer available against the award (Art. 1(2) (d)). This requirement is abolished by the New York Convention. Hence, it is no longer necessary to obtain an exequatur in the country where the award was made, before recognition and enforcement in another country can be sought. This new system is based on the idea that the requirement of an exequatur in the country of rendition entails unnecessary formalities and costs when the enforcement is not sought in that country but in another" 64 .

61 SANDERS, Pieter. "The History of the New York Convention". En Improving the Efficiency of Arbitration Agreements and Awards: 40 Years of Application of the New York Convention, ICCA Congress Series Volume 9, van den Berg, Albert Jan (ed.); Kluwer Law International, 1999, p 12.

62 VAN DEN BERG, Albert Jan. The New York Convention of 1958. Kluwer Law and Taxation Publishers, La Haya, 1981, p. 9.

63 Tribunal Federal Suizo, Joseph Mueller AG v. Bergesen, 26 de febrero de 1982. En YBK IX 1984, Pieter Sanders (ed.), Kluwer Law International, 1984, pp. 437-441.

64 Corte de Distrito de La Haya, German (F.R.) party v. Dutch party, 26 de abril de 1973. En YBK 
Como vemos, la abolición del doble exequátur facilita el reconocimiento de laudos arbitrales ya que permite ahorrar recursos en un reconocimiento para que el laudo se pueda reconocer en otro territorio. Así, por ejemplo, si dos partes quieren arbitrar en un tercer Estado que no tiene ninguna relación con la controversia, donde ninguna de las partes tiene bienes y que, por lo tanto, no se va a ejecutar el laudo arbitral en este territorio no tiene ningún sentido exigirle a la parte vencedora del laudo busque la ejecución del laudo en ese país para que luego busque el reconocimiento del laudo en el territorio donde sí tiene bienes con los cuales cobrar su laudo victorioso. Por ello, consideramos que la Convención de Nueva York correctamente abolió el sistema del doble exequátur.

\section{iv. Inversión de la carga de la prueba}

La Convención de Nueva York invirtió la carga de la prueba sobre la validez del laudo arbitral, creando una presunción de que el mismo es válido. Claro está que dicha presunción puede ser rebatida por el demandado.

Como explicamos anteriormente, bajo la regulación de la Convención de Ginebra, la parte que solicitaba el reconocimiento debía acreditar la validez del laudo y que no existían fundamentos para que se deniegue el reconocimiento (orden público, composición del Tribunal Arbitral, que los árbitros no excedan los términos del acuerdo arbitral, que el laudo era firme, entre otras). La Convención de Nueva York eliminó ese sistema e invirtió la carga de la prueba de la validez del laudo arbitral, estableciéndola en la cabeza de quien se opone al reconocimiento del laudo arbitral.

Así, como indican los profesores Fouchard, Gaillard y Goldman:

"As regards the conditions for recognition and enforcement of awards, the New York Convention makes significant progress in two areas as compared to the 1927 Geneva Convention. First, the burden of proof is reversed: once the award and arbitration agreement have been submitted by the party applying for recognition and enforcement of the award (Art. IV), the party opposing enforcement must prove why the award should not be enforced against it (Art. V)" 65 .

En ese mismo sentido, se pronuncia van den Berg:

1979 Volume IV, Sanders, Pieter (ed.), Kluwer Law International, 1979, pp. 305-306.

"(quoting Explanatory Memorandum of the Dutch [Arbitration] Act of 14 October 1963 implementing the New York Convention)".

65 GAILlARD, Emmanuel y SAVAGE, John. Fouchard Gaillard Goldman on International Commercial Arbitration. Kluwer Law International, 1999, p.124. 
"A further improvement is that the burden of proof is shifted from the party seeking enforcement to the party against whom the enforcement is sought. All the party seeking enforcement must do according to Article IV is to supply the arbitration agreement and the award. It is then up to the other party to prove the existence of one of the grounds for refusal limitatively set out in Article $\mathrm{V}(1)$. Article $\mathrm{V}(2)$ adds that enforcement may be refused by a court on its own motion if the subject matter of the difference is not capable of settlement by arbitration or if the award is contrary to the public policy of that country" 66 .

Esto ha sido señalado expresamente por la Corte de Justicia de Ginebra, ${ }^{67}$ por el Tribunal Supremo Español,68 la Corte de Distrito de Jerusalén,69 la Corte Superior de Nueva Delhi. ${ }^{70}$ Asimismo, en palabras de la Corte del Segundo Circuito de los Estados Unidos:

“The 1958 Convention's basic thrust was to liberalize procedures for enforcing foreign arbitral awards: While the Geneva Convention placed the burden of proof on the party seeking enforcement of a foreign arbitral award and did not circumscribe the range of available defenses to those enumerated in the convention, the 1958 Convention clearly shifted the burden of proof to the party defending against enforcement and limited his defenses to seven set forth in Article V"71.

Como queda claro, con la finalidad de propiciar el reconocimiento del laudo arbitral, es la parte quien se opone al reconocimiento la que tiene la carga de

66 VAN DEN BERG, Albert Jan. The New York Convention of 1958, Kluwer Law and Taxation Publishers, La Haya, 1981, p. 9.

67 Corte de Apelaciones de Canton de Ginebra, Carbomin S.A. v. Ekton Corporation, 14 de abril de 1983. En YBK 1987 Volume XII, van den Berg, Albert Jan (ed.), Kluwer Law International, 1987, pp. 502-504.

"New York Convention shifts the burden of proof by placing it on the defendant".

68 Tribunal Supremo Español, Cominco France S. A. v. Soquiber S. L., 24 de marzo de 1982. En YBK 1983 Volume VIII, van den Berg, Albert Jan (ed.), Kluwer Law International, 1983, pp. 408-409.

"This shift of the burden of proof is clearly affirmed in the introductory sentence of Art. V, para. 1, of the Convention (...)".

69 Corte de Distrito de Jerusalén, Epis S.A. v. Roche Diagnostics GmbH, 23 de noviembre de 2004. En: YBK 2006 Volume XXXI, van den Berg, Albert Jan (ed.), Kluwer Law International, 2006, pp. 786-790, ๆ 2.

"It is a basic rule with respect to the New York Convention that the burden of proof regarding the finality of the award is placed on the party seeking to resist confirmation."

70 Corte Suprema de la India, Escorts Ltd v. Universal Tractor Holding LLC, Special Leave Petition (Civil) No. 35092 de 2012. En: YBK 2014 Volume XXXIX, van den Berg, Albert Jan (ed.), Kluwer Law International, 2014, pp. 406-407.

"apart from the two innovations of the New York Convention viz., abandonment of the 'double exequatur' rule and shifting the burden of proving that the Award had not become final on the party resisting enforcement, the other change was that the concept of a "final Award" under the Geneva Convention was replaced by the concept of a 'binding Award.'

71 Corte de Apelaciones, Segundo Circuito, Parsons \& Whittemore Overseas Co. Inc. v. Société Générale de l'Industrie du Papier (RAKTA), Bank of America, 23 de diciembre de 1974. 
acreditar que el laudo no es válido y, por lo tanto, la encargada de acreditar las razones por las que el laudo no se debe reconocer. En tal sentido, el laudo se reputa válido y la carga de demostrar que ello no es así quedará en la parte que se opone al mismo.

\section{v. Principio de máxima eficacia}

El artículo VII de la Convención de Nueva York permite que los Estados apliquen disposiciones más favorables para el reconocimiento de laudos arbitrales sea que se encuentren en otro tratado o en su propia legislación nacional.72. Es claro el matiz pro-reconocimiento de la Convención de Nueva York.

Así pues, el artículo VII(1) de la Convención de Nueva York establece que:

"Las disposiciones de la presente Convención no afectarán la validez de los acuerdos multilaterales o bilaterales relativos al reconocimiento y la ejecución de las sentencias arbitrales concertados por los Estados Contratantes ni privarán a ninguna de las partes interesadas de cualquier derecho que pudiera tener a hacer valer una sentencia arbitral en la forma y medida admitidas por la legislación o los tratados del país donde dicha sentencia se invoque"73.

A esta disposición se le conoce como el principio de máxima eficacia y es otra de las reglas más importantes de este tratado. Como bien nos ilustran, Fouchard, Gaillard y Goldman, el principio de máxima eficacia soluciona dos tipos de problemas:

"First, it resolves conflicts between international conventions: the convention which prevails is neither the most recent, nor the most specific, but instead that which is most favorable to enforcement of the award. This ties in with the idea of the "maximum effectiveness" of each treaty.

The second type of conflict avoided through the application of the "morefavourable-right provision" is that between the rules of the New York Convention and those of the law of the contracting state in which the award is to be enforced. The traditional solution to such a conflict, whereby international treaties prevail over national laws, is thus rejected. The

72 BORN, Gary. International Commercial Arbitration. 2da edición, Kluwer Law International, 2014, p. 233: "Article VII makes it clear that nothing in the Convention limits a party's rights to enforce an arbitration agreement under national laws, where these are more favorable than the terms of the Convention itself."

73 Convención de Nueva York. Artículo VII. 
contracting states clearly intended that the Convention provide only the minimum level of protection for the beneficiary of the award" 74 .

De esta manera, en primer lugar, el principio de máxima eficacia contenido en la Convención de Nueva York elimina el conflicto entre tratados potencialmente aplicables estableciendo que se aplicará aquel que sea más favorable a efectos del reconocimiento.

Por consiguiente, como se puede apreciar, bajo el paraguas de la Convención de Nueva York, los Estados pueden convenir en sus tratados que existan disposiciones más favorables para conceder el reconocimiento y ejecución de laudos arbitrales extranjeros. Así pues, a través de tratados bilaterales o multilaterales, estos pueden convenir, por ejemplo, que no exista una determinada causal para denegar el reconocimiento que sí existe bajo la Convención de Nueva York o que no se exija un requisito para presentar el exequátur. Por lo tanto, bajo la aplicación del principio de máxima eficacia de la Convención de Nueva York podemos acudir a los tratados aplicables suscritos por el Estado que sean más favorables para el reconocimiento.

El principio de máxima eficacia contenido en la Convención de Nueva York establece que se aplicará la norma más favorable para el reconocimiento, sin importar si esta se encuentra en la legislación nacional. Así, se aplicarán las disposiciones nacionales si son más favorables para la ejecución. De este modo se descarta el principio por el que los compromisos internacionales prevalecen sobre la legislación local. Al contrario, si la legislación nacional es más favorable que la legislación internacional para reconocer el laudo, se aplicará la legislación nacional pues así lo dispone el propio Tratado. Como vemos, estas disposiciones tienen una marcada tendencia a facilitar el reconocimiento y la ejecución de los laudos arbitrales extranjeros.

En efecto, esto ha sido reconocido explícitamente por las cortes. Por ejemplo, una corte alemana ha señalado que:

"The New York Convention allows for the application of national law where it is more favorable for the recognition and enforcement of the arbitral award. ... Hence, a German court may rely on domestic law in its entirety that is more friendly to recognition. (...) The more-favorable-right principle (Article VII(1)) is generally understood to allow for the application of domestic provisions that are less strict that Article II(2), such as $\$ 1031$ of the ZPO [i.e., the German international arbitration statute]" 75.

74 GAILLARD, Emmanuel y SAVAGE, John. Fouchard Gaillard Goldman on International Commercial Arbitration, Kluwer Law International, 1999, pp. 133-134.

75 Corte Federal de Alemania, No identificado v. No identificado, 21 de septiembre de 2005. En 
En esta línea, bajo el paraguas de la Convención de Nueva York, las cortes aplicarán al momento de resolver el reconocimiento de los laudos arbitrales extranjeros su propia legislación nacional en materia de reconocimiento de laudos arbitrales si es que esta norma es más favorable para el reconocimiento del laudo arbitral.

En consecuencia, la Convención de Nueva York permite que los Estados establezcan en su propia legislación nacional disposiciones más favorables para el reconocimiento y ejecución de laudos arbitrales extranjeros. Esto también es parte del principio de máxima eficacia.

\section{vi. Establece las máximas causales que un Estado puede utilizar para denegar el reconocimiento de un laudo}

La Convención de Nueva York no permite a los Estados que establezcan más causales de las listadas en su artículo $\mathrm{V}$ para que se deniegue el reconocimiento de laudos arbitrales extranjeros en aras de facilitar el reconocimiento.

Hasta antes de que entrara en vigor la Convención de Nueva York cada Estado tenía absoluta libertad de determinar bajo qué razones se podía denegar el reconocimiento de un laudo arbitral extranjero. Hemos visto líneas arriba que bajo el artículo 4 de la Convención de Ginebra se permitía a los Estados denegar el reconocimiento de un laudo bajo lo que establezca su legislación nacional.

La mencionada dificultad se eliminó con la Convención de Nueva York. A partir de la Convención de Nueva York, los Estados sólo pueden denegar el reconocimiento de un laudo arbitral por las siete causales previstas en el artículo $\mathrm{V}$ de este dispositivo internacional. Cinco de las causales deben ser alegadas y probadas por la parte que se opone al reconocimiento y dos que pueden ser apreciadas de oficio por las cortes.

Así pues, los Estados parte de la Convención de Nueva York (y sus cortes) no pueden denegar el reconocimiento de un laudo extranjero por causales distintas a las contempladas en dicho tratado. Los Estados solo pueden basarse en alguna de las causales de este tratado. Hacer lo contrario, violaría la Convención de Nueva York.

En casi 60 años de vida del tratado, los Estados han acatado lo dispuesto en la Convención de Nueva York no estableciendo más motivos de denegación del reconocimiento de los previstos en el artículo $\mathrm{V}$ de la Convención de Nueva York.

YBK 2006 Volume XXXI, van den Berg, Albert Jan (ed.), Kluwer Law International, 2006, pp. 679-684. 
La Ley Modelo UNCITRAL de 1985 repitió exactamente las mismas causales de la Convención de Nueva York para denegar el reconocimiento de laudos arbitrales ratificando que no se pueden establecer mayores causales para denegar el reconocimiento de un laudo anulado. De hecho, la propia Nota Explicativa de UNCITRAL sobre la Ley Modelo UNCITRAL manifiesta que:

“Al estipular normas sobre el reconocimiento y la ejecución que siguen el modelo de las disposiciones pertinentes de la Convención de Nueva York, la Ley Modelo complementa el régimen de reconocimiento y ejecución creado por esa exitosa Convención sin entrar en conflicto con él. (...) los motivos por los que podrá denegarse el reconocimiento o la ejecución en virtud de la Ley Modelo son idénticos a los del artículo V de la Convención de Nueva York" 76.

Por ello, no podemos sino coincidir con Pieter Sanders, quien indica que el impacto de la Convención de Nueva York sobre la Ley Modelo UNCITRAL ha sido considerable ${ }^{77}$.

Por tanto, ya sea porque los Estados forman parte de la Convención de Nueva York o porque son países seguidores de la Ley Modelo UNCITRAL, la mayoría de Estados han terminado por prever en su legislación las mismas causales de denegación de reconocimiento de un laudo arbitral.

Esto sin duda genera predictibilidad en los actores del sistema arbitral. Es decir, las partes de un arbitraje pueden saber de antemano cuáles pueden ser los motivos bajo los cuales se puede denegar el reconocimiento de un laudo dictado en otra jurisdicción.

\section{Conclusiones}

Como hemos podido analizar, la Convención de Nueva York tiene una

76 Comisión de las Naciones Unidas para el Derecho Mercantil Internacional, Nota explicativa de la secretaría de la CNUDMI acerca de la Ley Modelo sobre Arbitraje Comercial Internacional, 1985, en su versión enmendada en 2006. Disponible en: https:// www.uncitral.org/pdf/spanish/texts/arbitration/ml-arb/07-87001_Ebook.pdf, Consulta realizada el día 7 de noviembre de 2016.

77 SANDERS, Pieter. "The History of the New York Convention". En Improving the Efficiency of Arbitration Agreements and Awards: 40 Years of Application of the New York Convention, ICCA Congress Series Volume 9, van den Berg, Albert Jan (ed.), Kluwer Law International, 1999, p. 13.

"First of all I would like to draw attention to the harmonizing effect the New York Convention has had on national arbitration legislation. This development was not foreseen in 1958. It is thanks to the UNCITRAL Model Law of 1985 which virtually repeats the grounds for refusal of enforcement of the New York Convention in its model for national arbitration legislation. This was done not only for the grounds for the refusal of enforcement of an award but virtually the same grounds apply as grounds for the setting aside of an award. The Model Law has by now been adopted by some 28 States of which 10 also did so for domestic arbitration. Therefore, the impact of the New York Convention on the Model Law has been considerable". 
marcada tendencia a favor del reconocimiento de laudos arbitrales extranjeros. De esta manera, se busca incentivar y no perjudicar el comercio internacional y el flujo de las inversiones transfronterizas. Su ámbito de aplicación es sumamente amplio y busca tener un alcance universal.

Producto del objetivo señalado, este tratado elimina el absurdo doble exequátur existente hasta el momento en que se dicta la Convención de Nueva York. Como hemos desarrollado, la Convención de Ginebra exigía que el laudo arbitral debía pasar por la ejecución en la sede del arbitraje para que recién cuando ello ocurra, se pueda reconocer en otro Estado.

Asimismo, la Convención de Nueva York invierte la carga de la prueba de la validez del laudo arbitral y la coloca en la parte que se opone al reconocimiento. De esta manera, el laudo goza de una presunción de validez y es la parte que solicita que se deniegue el reconocimiento la que debe probar por qué el laudo arbitral no debe ser reconocido en base a alguna de las razones contenidas en el Artículo V de la Convención de Nueva York.

Por último, la Convención de Nueva York permite a las cortes aplicar las normas más favorables para otorgar el reconocimiento, sea que estas se encuentren en otro tratado aplicable o en la propia legislación nacional del lugar donde se solicita el reconocimiento del laudo arbitral.

Por todo lo antes dicho, podemos afirmar, sin duda alguna, que la Convención de Nueva York ha sido el más importante hito en el Arbitraje Comercial Internacional, $\mathrm{y}$ ha dotado a esta institución de los fundamentos que hoy asumimos como naturales a la misma.

No podemos dejar de lado además que este tratado, pese a ya tener casi 60 años de vigencia, continúa generando interesantes debates, como la posibilidad de reconocer laudos anulados, por ejemplo, y estamos seguros que lo seguirá haciendo, siendo esta la principal muestra de su relevancia y presencia. 